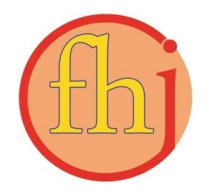

Faletehan Health Journal, 7 (1) (2020) 18-29

www. journal.Ippm-stikesfa.ac.id/ojs/index.php/FHJ

ISSN 2088-673X | e-ISSN 2597-8667

\title{
Faktor-Faktor Yang Berhubungan Dengan Pemberian ASI Eksklusif Pada Ibu Bekerja di Kelurahan Cipare Kota Serang
}

\author{
Nila M arwiyah ${ }^{1 *}$, Titi Khaerawati ${ }^{1}$ \\ ${ }^{1}$ Fakultas IImu Kesehatan Universitas Faletehan, Serang, Indonesia \\ *Corresponding Author: nila_marwiyah@yahoo.com
}

\begin{abstract}
Abstrak
Angka kematian pada bayi dan balita bisa disebabkan oleh karena bayi tidak mendapatkan ASl eksklusif. Salah satu faktor tidak cukupnya pemberian ASI karena kesulitan ibu dalam hal menyusui, terutama bagi ibu-ibu yang bekerja. Tujuan dari penelitian ini adalah untuk mengetahui faktor-faktor yang berhubungan dengan pemberian ASI eksklusif pada ibu bekerja di Kelurahan Cipare wilayah Kerja Puskesmas Serang Kota. Desain penelitian adalah korelasi dengan menggunakan cross sectional. Tekhnik sampling yang digunakan adalah purposive sampling dengan sampel 51 responden. Analisis data univariat disajikan dengan distribusi frekuensi, sedangkan analisis bivariat menggunakan Chi Square. Hasil analisis univariat penelitian ini menunjukan bahwa sebagian besar responden tidak memberikan ASI eksklusif dan hampir sebagian besar responden mendapatkan dukungan dari atasannya. Hasil analisis bivariat penelitian ini ada hubungan antara pemberian ASI eksklusif dengan status paritas ( $p$ value $=0,011$ ), pendidikan ( $p$ value $=0,037$ ), pengetahuan ( $p$ value $=0,035$ ), dukungan keluarga ( $p$ value $=0,006$ ) dan dukungan atasan ( $p$ value $=0,006$ ). Pemahaman tentang pentingnya pemberian ASI Eksklusif pada bayi sangat membantu ibu bekerja dalam memberikan ASInya selama 6 bulan. Adapun Hasil penelitian ini dapat menjadi dasar untuk mengevaluasi ibu pekerja agar mengoptimalkan pemanfaatan ruang laktasi dan tetap memberikan ASl eksklusif kepada bayinya.
\end{abstract}

Kata Kunci: ASI Eksklusif, Dukungan Keluarga, Ibu Bekerja

\section{Factors Associated with Exclusive Breastfeeding for Working Mothers in Cipare Village Serang City}

\begin{abstract}
Infant and child mortality rate may be caused by not getting exclusive breastfeeding. One of the factors of inadequate breastfeeding is mothers difficulty in breastfeeding, especially working moms. The purpose of this research is to identify factors related to exclusive breastfeeding among working moms in Cipare Village at WorkArea of Serang City Community Health Center. The research design is cross sectional. The sampling technique is purposive sampling with 51 respondents. The univariate data analysis was presented by frequency distribution, while the bivariate analysis by chi square. The univariate analysis showed that almost respondents did not give exclusive breastfeeding and almost respondents got support from their boss. The results of bivariate analysis showed a correlation between exclusive breastfeeding and parity status ( $p$ value 0.011 ), education background ( $p$ value 0.037 ), knowledge ( $p$ value 0.035 ), family support ( $p$ value 0.006 ), and boss support ( $p$ value 0.006 ). The understanding of the importance of exclusive breastfeeding really helps working moms breastfeed during 6 months. The research results may be a basis of evaluating working moms to optimize the use of lactation room and to keep exclusive breastfeeding for their babies.
\end{abstract}

Keywords: Exclusive Breastfeeding, Family Support, Working Moms 
Faletehan Health Journal, 7 (1) (2020) 18-29

www. journal.Ippm-stikesfa.ac.id/ojs/index.php/FHJ

ISSN 2088-673X | 2597-8667

\section{Pendahuluan}

Air Susu Ibu (ASI) merupakan cairan yang keluar langsung dari payudara seorang ibu untuk bayi. ASI merupakan makanan bayi yang paling sempurna, praktis, murah dan bersih karena langsung diminum dari payudara ibu. ASI mengandung semua zat gizi dan cairan yang dibutuhkan bayi untuk memenuhi kebutuhan gizi di 6 bulan pertamanya. Jenis ASI terbagi menjadi 3 yaitu kolostrum, ASI masa peralihan dan ASI mature. ASI memiliki kandungan gizi dan imunitas yang sangat penting bagi bayi (Adhi, 2013).

Empat Standar Emas Nutrisi Bayi, yaitu Inisiasi Menyusu Dini (IMD) pada satu jam pertama segera setelah bayi lahir dilanjutkan dengan rawat gabung, Memberikan hanya ASI saja sejak lahir sampai bayi berumur enam bulan, memberikan makanan pendamping ASI (MP-ASI) mulai umur enam bulan, dan Menyusui dilanjutkan sampai anak berumur 24 bulan (Adhi, 2013).

Dalam teori continum of care dijelaskan bahwa seribu hari pertama kehidupan seorang manusia yang terhitung sejak dalam janin sampai usia dua tahun merupakan fase penting yang bukan hanya berpengaruh terhadap jangka pendek akan tetapi jangka panjang kehidupan mereka (Jalal, 2014). Salah satu hal yang direkomendasikan untuk memenuhi fase penting dalam periode enam bulan pertama adalah pemberian air susu ibu (ASI) Eksklusif. United Nations International Children's Emergency Fund (UNICEF) dan WHO (2011) juga merekomendasikan sebaiknya anak hanya disusui air susu ibu (ASI) selama paling sedikit enam bulan untuk menurunkan angka kesakitan dan kematian anak. Pemerintah Indonesia mengubah rekomendasi pemberian ASI eksklusif dari empat bulan menjadi enam bulan.

ASI eksklusif sangat penting bagi kelangsungan hidup bayi (Ballard \& Morrow, 2013). ASI mengandung growth faktor dan zat antibodi. Growth faktor dalam ASI berperan dalam membantu proses pematangan organ dan hormon, sedangkan zat antibodi berfungsi membantu proses pematangan sistem imun. Proses pematangan sistem imun sangat penting karena sistem imun bayi baru lahir belum sempurna. Apabila ASI tidak diberikan secara eksklusif, proses pematangan sistem imun akan terganggu dan menyebabkan bayi mudah terserang infeksi. Penanganan infeksi yang terlambat dapat memicu kematian (Buonocore, Bracci, \& Weindling, 2013). Selain itu, kegagalan ASI eksklusif juga dapat mengganggu proses pematangan organ dan hormon.

Pemberian ASI secara Eksklusif dapat mencegah kematian balita sebanyak 13\% (Nurheti, 2010). Pemberian makanan pendamping ASI dengan jumlah yang tepat dapat mencegah kematian balita sebanyak $6 \%$ sehingga pemberian ASI secara eksklusif selama 6 bulan dan dilanjutkan sampai usia > 2 tahun bersama makanan pendamping ASI yang tepat dapat mencegah kematian balita sebanyak $19 \%$. Keputusan Menteri Kesehatan Republik Indonesia No. 450/Men.Kes/SK/IV/2004 menyatakan bahwa bahwa Air Susu Ibu (ASI) adalah makanan terbaik bagi bayi karena mengandung zat gizi paling sesuai untuk pertumbuhan dan perkembangan bayi. Selanjutnya untuk mencapai pertumbuhan dan perkembangan bayi yang optimal ASI perlu diberikan secara Eksklusif sampai umur 6 (enam) bulan dan dapat dilanjutkan sampai anak berumur 2 (dua) tahun.

ASI eksklusif dapat menekan angka kematian bayi di Indonesia dan dapat menyelamatkan 1,3 juta jiwa di seluruh dunia. UNICEF menyatakan bahwa 30.000 kematian bayi di Indonesia dan 10juta kematian anak balita di dunia setiap tahun bisa dicegah melalui pemberian ASI eksklusif selama enam bulan sejak sejam pertama setelah kelahirannya tanpa memberikan makanan dan minuman tambahan kepada bayi (Proverawati, 2010).

Kematian perinatal diseluruh dunia sekitar 10 juta persalinan hidup dengan catatan bahwa sekitar 98-99\% terjadi di Negara berkembang, dimana angka kematian perinatal seratus kali lebih besar dari pada negara maju. Salah satu penyebab kematian tersebut adalah kurangnya akses keperawatan kesehatan bagi neonatal. Sebanyak 136.700.000 bayi dilahirkan diseluruh dunia dan hanya $32,6 \%$ dari mereka yang mendapat ASI secara eksklusif pada usia 0 sampai 6 bulan pertama. Hal tersebut menggambarkan cakupan pemberian ASI Eksklusif di bawah $80 \%$ dan masih sedikitnya ibu yang memberikan ASI Eksklusif pada bayi (WHO, 2011).

Indikator utama derajat kesehatan masyarakat adalah Angka Kematian Bayi (AKB) atau Infant Mortality Rate (IMR). AKB tidak berdiri sendiri, melainkan berkaitan dengan beberapa faktor lain seperti tingkat keberhasilan program KIA dan 
pencapaian perbaikan gizi masyarakat salah satunya adalah pemberian ASI Eksklusif. Tahun 2015 Indonesia menargetkan penurunan sebesar $23 \%$ untuk angka kematian bayi dan balita dalam kurun waktu 2009-2015. Oleh sebab itu Indonesia mempunyai komitmen untuk menurunkan angka kematian bayi dari 68/1.000 kelahiran hidup menjadi 23/1.000 kelahiran hidup dan angka kematian balita dari 97/1.000 kelahiran hidup menjadi 32/1.000 kelahiran hidup. Untuk mencapai targetmenurunkan AKB, dapat dilakukan salah satunya dengan pemberian ASI Eksklusif (Prasetyono, 2012).

Berdasarkan Data Riset Kesehatan Dasar tahun 2013 menunjukkan bahwa bayi yang mendapat ASI Eksklusif secara nasional sebesar $15,3 \%$. Angka tersebut masih jauh dari target yang telah ditetapkan, yakni sebesar $80 \%$. Sedangkan berdasarkan Pemantauan Status Gizi Tahun 2016, Ditjen. Kesehatan Masyarakat, Kemenkes RI, 2013 bahwa cakupan pemberian ASI Eksklusif 0-6 bulan tahun 2016 di Banten sebanyak 38,5\%. Angka tersebut masih jauh dari target yang telah ditetapkan, yakni sebesar $80 \%$. Berdasarkan laporan rekapitulasi pencatatan ASI Eksklusif di Serang Kota pada tahun 2016 dan 2017 sebanyak $72,5 \%$ tidak ada peningkatan dan jauh dari target yang telah ditetapkan. Kegagalan praktek Pemberian ASI eksklusif disebabkan oleh bermacam-macam hal seperti pemberian makanan prelakteal, ibu harus bekerja, ibu lelah/ sakit, dan lain-lain. Berdasarkan penelitian ibu mendapatkan informasi yang salah tentang manfaat ASI eksklusif, mengenai cara menyusui yang benar, dan apa yang harus dilakukan bila timbul kesukaran dalam menyusui. Proses pemberian ASI bisa saja mengalami hambatan dikarenakan produksi ASI berhenti (Febriyanti \& Ernawati, 2014).

Hambatan dalam pemberian ASI Eksklusif antara lain ASI keluar sedikit, ibu takut payudara turun, dan ibu bekerja. Beberapa faktor yang mempengaruhi pemberian ASI eksklusif antara lain faktor internal yaitu pengetahuan, faktor psikologis, faktor fisik ibu, faktor perilaku sedangkan faktor eksternal atau faktor dari luar diri ibu juga dapat berpengaruh, antara lain keyakinan yang keliru yang berkembang dalam masyarakat, faktor sosial ekonomi, maupun kurangnya dukungan terhadap ibu dari tenaga kesehatan, petugas penolong persalinan, lingkungan ketika ibu bekerja, maupun orang-orang terdekat ibu seperti keluarga atau suami (Soetjiningsih, 2012). Dalam penelitian ini, yang diteliti adalah faktor dari luar diri ibu yaitu dukungan dari suami dan dukungan tempat bekerja atau dukungan atasan, serta faktor dari dalam diri ibu yaitu paritas, pengetahuan dan sikap ibu terhadap pemberian ASI.

Data dari Badan Pusat Statistik terbaru, tingkat partisipasi pekerja perempuan meningkat menjadi 51,09\% dari tahun sebelumnya yang berada di angka 48,90\% dan saat ini pekerja perempuan mencapai 86,7 juta orang. Masih terdapat banyak ibu menyusui yang bekerja sehingga hal tersebut menyebabkan pemberian ASI eksklusif kurang optimal, tenaga kerja perempuan yang meningkat menjadi salah satu kendala dalam meningkatkan keberhasilan program ASI Eksklusif karena cuti melahirkan hanya 12 minggu, dimana empat minggu diantaranya sering harus diambil sebelum melahirkan. Dengan demikian, ibu yang bekerja hanya dapat menemani bayinya secara intensif hanya dua bulan termasuk dalam penyusuan bayinya. Setelah itu ibu harus kembali bekerja dan sering ibu terpaksa berhenti menyusui (Badan Pusat Statistik, 2015).

Menyeimbangkan antara karir dengan menyusui sebenarnya tergantung dari manajemen waktu ibu. Jika ibu dapat mengatur waktunya dengan baik dan tidak mengganggu operasional kantor maka hal tersebut tidak menjadi masalah. Keadaan tersebut juga dimudahkan dengan adanya kemajuan teknologi dan kemajuan di bidang kedokteran, serta adanya pengetahuan tentang ASI yang semakin baik. Jika demikian maka tidak ada alasan apapun bagi ibu untuk tidak dapat menyeimbangkan antara karir dan menyusui (Yulianti, 2014).

Pada penelitian Nasution, Liputo, \& Masri (2014) di Wilayah Kerja Puskesmas Bungus menyatakan bahwa pemberian ASI tidak eksklusif lebih banyak pada Ibu yang tidak bekerja $(78,7 \%)$, dibandingkan dengan Ibu yang bekerja $(71,4 \%)$. Bekerja umumnya merupakan kegiatan yang menyita waktu sehingga kesempatan untuk mendapatkan informasipun lebih sedikit sehingga tingkat pengetahuan mereka juga berkurang. Terbatasnya waktu juga menyebabkan pemberian ASI kepada bayinya menjadi berkurang.

Berdasarkan informasi dari bidan desa Cipare Wilayah Kerja Puskesmas Serang Kota, mengungkapkan bahwa di Posyadu Melati banyak ibu menyusui tidak dapat menyeimbangkan antara 
Faletehan Health Journal, 7 (1) (2020) 18-29

www. journal.Ippm-stikesfa.ac.id/ojs/index.php/FHJ

ISSN 2088-673X | 2597-8667

karir dan menyusui yang dikarenakan ibu harus bekerja untuk mencukupi kebutuhan sehari-hari meskipun sebenarnya ibu sangat ingin berada dirumah untuk mengasuh anaknya. Dari hasil studi pendahuluan di Posyandu Melati Desa CipareWilayah Kerja Puskesmas Serang Kota, dari 10 ibu yang memiliki anak, 8 orang tidak menyusui selama 6 bulan sedangkan 2 orang ibu yang memberikan ASI Eksklusif selama 1 tahun.

\section{Metode Penelitian}

Penelitian ini menggunakan desain penelitian korelasi dengan cross sectional. Populasi dalam penelitian ini sebanyak 778 ibu pekerja yang memiliki anak $>6$ bulan. Sample yang dilibatkan dalam penelitian adalah sejumlah 51 ibu pekerja, dengan teknik sampling yang digunakan adalah simple random sampling. Penelitian ini dilaksanakan di Kelurahan Cipare wilayah kerja Puskesmas Serang Kota dimulai sejak 25 Agustus 2018 sampai bulan Januari 2019. Analisis univariat menggunakan distribusi frekuensi dan analisis bivariat menggunakan uji Chi Square.

Instrumen yang digunakan telah di uji validitas dan reliabilitas, kuesioner dukungan atasan hasil analisis untuk 9 item pertayaan tentang dukungan atasan ditempat kerja dengan $r$ hitung $(0,507-0,877)$ dan uji reliabilitas diperoleh $r$ hitung 0,910. Kuesioner Pengetahuan ASI eksklusif hasil analisis untuk 20 item pertanyaan tentang pengetahuan Asi Eksklusif dengan r hitung $(0,537$ 0,866 ) dan uji reliabilitas diperoleh $r$ hitung 0,952 . Kuesioner dukungan keluarga hasil analisis untuk 22 item pertanyaan tentang dukungan keluarga dengan $r$ hitung $(0,601-0,849)$ dan uji reliabilitas diperoleh $r$ hitung 0,959 .

\section{Hasil dan Pembahasan}

Berdasarkan hasil analisis data pada tabel 1 menunjukkan bahwa sebagian besar responden ibu pekerja tidak memberikan ASI Eksklusif. Josefa dan Margawati (2011) menyatakan bahwa sebagian besar ibu yang bekerja kurang fokus dalam mengurus anak terutama dalam pemberian ASI eksklusif, hal ini disebabkan karena kesibukan di tempat kerja sehingga waktu untuk memompa ASI lebih sedikit dan bahkan tidak bisa. Selain itu sarana dan prasarana yang tidak mendukung dan tingkat stress di tempat kerja juga mengakibatkan penurunan produksi ASI.
Ibu yang gagal dalam memberikan ASI Eksklusif kepada bayi juga telah memberikan makanan prelaktal dan memberian PASI usia dini. Ibu yang gagal dalam memberikan ASI Eksklusif kepada bayi mengatakan bahwa ASI belum keluar sehingga bayi langsung diberikan susu formula. Selain itu, pada ibu yang gagal dalam memberikan ASI Eksklusif kepada bayi juga beranggapan bahwa memberikan ASI saja tidak dapat mencukupi kebutuhan bayi, sehingga jika bayi terus rewel ibu memberikan susu formula kepada bayi. Pekerjaan rumah yang menguras waktu dan tenaga juga menjadi penyebab ibu tidak memberikan ASI eksklusif (Timporok, Wowor, \& Rompas, 2018).

Penelitian ini juga menunjukkan hasil yang sama dengan penelitian Dahlan Mubin, \& Mustika (2013) bahwa ibu yang bekerja memiliki resiko untuk tidak memberikan ASI eksklusif, hal itu dikarenakan banyak waktu yang ibu habiskan untuk pekerjaannya. Namun sebaliknya bila status ibu adalah tidak bekerja maka besar kemungkinan bagi ibu untuk memberikan ASI eksklusif, karena banyak waktu luang ibu yang dapat digunakan untuk merawat dan memberikan kasih sayang untuk bayinya.

Ibu yang bekerja di Kelurahan Cipare Wilayah Kerja Puskesmas Serang Kota tidak menerapkan Peraturan Bersama Menteri Negara Pemberdayaan Perempuan, Menteri Tenaga Kerja dan Transmigrasi, dan Menteri Kesehatan (No.48/Men.PP/XII/2008, No. PER.27/MEI I/XII/2008 dan No.1177/Menkes/PB/XII/2008) tentang peningkatan pemberian air susu ibu selama waktu kerja di tempat kerja. Di mana ibu-ibu seharusnya memiliki kesempatan untuk menyusui atau mengeluarkan ASI untuk bayinya di tempat kerja. Hal ini yang menyebabkan banyak ibu yang bekerja tidak menerapkan pemberian ASI eksklusif selama 6 bulan.

Tabel 1. Distribusi Responden berdasarkan pemberian ASI $(n=51)$

\begin{tabular}{lcc}
\hline \multicolumn{1}{c}{ Pemberian ASI } & F & \% \\
\hline Tidak ASI Eksklusif & 37 & 72,5 \\
ASI Eksklusif & 14 & 27,5 \\
\hline Jumlah & 51 & 100 \\
\hline
\end{tabular}


Berdasarkan hasil analisis data penelitian terlihat bahwa sebagian besar responden didominasi oleh ibu dengan status paritasnya primipara. Secara teoritis paritas diperkirakan ada kaitannya dengan arah pencarian informasi tentang pengetahuan ibu nifas/menyusui dalam memberikan ASI eksklusif. Hal ini dihubungkan dengan pengaruh pengalaman sendiri maupun orang lain terhadap pengetahuan yang dapat mempengaruhi prilaku saat ini atau kemudian.

Berdasarkan pendidikan ibu, hasil analisis data penelitian menunjukkan bahwa sebagian responden memiliki tingkat pendidikan yang tinggi. Tingkat pendidikan adalah tahapan pendidikan yang ditetapkan berdasarkan tingkat perkembangan peserta didik, tujuan yang akan dicapai dan kemauan yang dikembangkan. Tingkat pendidikan berpengaruh terhadap perubahan sikap dan perilaku hidup sehat. Pendidikan formal membentuk nilai bagi seseorang terutama dalam menerima hal baru (Prasetyono, 2012). Ibu yang mempunyai tingkat pendidikan yang lebih tinggi, umumnya terbuka menerima perubahan atau halhal guna pemeliharaan kesehatanya. Pendidikan juga akan membuat seseorang terdorong untuk ingin tahu mencari pengalaman sehingga informasi yang diterima akan menjadi pengetahuan.

Penelitian Lestari (2018) tentang penyebab gizi kurang pada anak menunjukkan bahwa tingkat pendidikan dalam keluarga khususnya Ibu dapat menjadi faktor yang mempengaruhi status gizi anak dalam keluarga. Semakin tinggi pendidikan orang tua maka pengetahuannya akan gizi akan lebih baik dari yang berpendidikan rendah. Salah satu penyebab gizi kurang pada anak adalah kurangnya perhatian orang tua akan gizi anak, hal ini disebabkan karena pendidikan dan pengetahuan gizi Ibu yang rendah. Pendidikan formal Ibu akan mempengaruhi tingkat pengetahuan gizi, semakin tinggi pendidikan Ibu, maka semangkin tinggi kemampuan untuk menyerap pengetahuan praktis dan pendidikan formal.

Menurut Undang- Undang No. 20 Tahun 2003 tentang Sistem Pendidikan Nasional, Semakin tinggi tingkat pendidikan seseorang, maka semakin mudah pula seseorang untuk menerima informasi. Informasi yang didapat seseorang nantinya akan mempengaruhi pengetahuan (Kurniawati, 2014). Dalam teori Health Belief Model, tingkat pendidikan termasuk dalam variable demografi yang merupakan salah satu faktor yang mempengaruhi persepsi seseorang untuk berperilaku karena tingkat pendidikan membentuk cara pikir seseorang (Priyoto, 2014).

Berdasarkan pengetahuan ibu, hasil analisis data menunjukkan bahwa sebagian responden ibu pekerja memiliki pengetahuan yang baik terhadap ASI Eksklusif. Pengetahuan merupakan domain yang cukup penting dalam menentukan perilaku. Perilaku yang didasari pengetahuan, kesadaran dan sikap positif akan semakin langgeng. Pengetahuan yang baik akan memudahkan seseorang untuk merubah perilaku termasuk dalam praktik menyusui. Perilaku ibu untuk memberikan ASI eksklusif disebabkan oleh faktor penyebab perilaku yang salah satunya adalah pengetahuan, dimana faktor ini menjadi dasaratau motivasi bagi individu dalam mengambil keputusan (Notoatmojo, 2014).

Adanya informasi tentang manajemen laktasi yang diperoleh ibu baik yang diperoleh ibu secara pribadi dan didukung oleh informasi yang diperoleh ketika melakukan kegiatan Posyandu membantu mereka dalam mengetahui dan memahami tentang pengetahuan manajemen laktasi yang baik dan benar. Status pekerjaan juga dapat berpengaruh terhadap tingkat pengetahuan. Menurut Notoatmodjo (2014) kemampuan seseorang dalam melakukan pekerjaan berbeda dengan orang lain, kemampuan tersebut dapat berkembang karena pendidikan dan pengalaman sehingga lingkungan pekerjaan dapat menjadikan seseorang memperoleh pengalaman dan pengetahuan baik secara langsung maupun tidak langsung.

Tabel 2. Distribusi responden menurut paritas, pendidikan, pengetahuan, dukungan keluarga dan dukungaan atasan $(\mathrm{n}=51)$

\begin{tabular}{lcc}
\hline \multicolumn{1}{c}{ Variabel } & f & \% \\
\hline Paritas & & \\
Primipara & 37 & 72,5 \\
Multipara & 14 & 27,5 \\
\hline $\begin{array}{l}\text { Pendidikan } \\
\text { Rendah }\end{array}$ & 21 & 41,2 \\
Tinggi & 30 & 58,8 \\
\hline Pengetahuan & & \\
$\quad$ Kurang & 25 & 49 \\
Baik & 26 & 51 \\
\hline Dukungan keluarga & & \\
$\quad$ Kurang mendukung & 27 & 52,9 \\
Mendukung & 24 & 47,1 \\
\hline Dukungan atasan & & \\
$\quad$ Kurang mendukung & 25 & 49 \\
$\quad$ Mendukung & 26 & 51 \\
\hline
\end{tabular}


Faletehan Health Journal, 7 (1) (2020) 18-29

www. journal.Ippm-stikesfa.ac.id/ojs/index.php/FHJ ISSN 2088-673X | 2597-8667

Berdasarkan dukungan keluarga, analisis data penelitian menunjukkan bahwa sebagian responden ibu pekerja kurang mendapatkan dukungan dari keluarga. Dalam pemberian ASI Eksklusif dukungan keluarga sangat penting, terutama suami. Dikarenakan menyusui kadang tidak mudah dan sangat melelahkan. Dari semua dukungan bagi ibu menyusui, dukungan suami adalah dukungan paling berarti bagi ibu. Suami dapat berperan aktif dalam keberhasilan pemberian ASI dengan jalan memberikan dukungan secara emosional dan bantuan praktis lainnya (Roesli,2008).

Dukungan keluarga dari sekitar ibu mempunyai peran yang besar terhadap keberhasilan menyusui. Dukungan itu berasal dari lingkungan disekitar ibu selain suami, juga ada keluarga misalnya nenek dan keluarga lain yang sudah mempunyai pengalaman menyusui, peran nenek biasanya yang lebih dominan terhadap ibu. Dukungan suami/keluarga yang bagus akan senantiasa mendukung ibu dalam menumbuhkan sikap yang positif dalam pemberian ASI (IDAI, 2010). Namun berdasarkan penelitian oleh Ayton \& Emily (2016) menyatakan bahwa Seorang ayah yang baru pertama kali memiliki anak beranggapan bahwa dukungan yang diberikan untuk menyusui bukan menjadi prioritas utama meskipun mereka mengetahui manfaat menyusui bagi bayi. Tetapi dukungan dan pengalaman dari komunitas akan memberikan dampak yang lebih positif. Hal ini berarti ayah kurang memahami tugasnya untuk mendukung ibu agar tetap dapat menyusui. Karena dukungan dari keluarga termasuk suami sangat penting dan berpengaruh pada keputusan yang akan diambil oleh seorang ibu.

Berdasarkan aspek dukungan atasan, hasil analisis data penelitian menunjukkan bahwa sebagian responden mendapatkan dukungan dari atasannya, Dalam kajian teori Health Belief Model, dukungan atasan langsung merupakan isyarat untuk melakukan tindakan. Dukungan yang diberikan dapat berupa dukungan informasional, appraisal, instrumenal dan emosional. Misalnya dengan memberikan informasi tentang manajemen laktasi dan ASI eksklusif serta memberikan waktu khusus untuk memerah ASI. Dengan dukungan tersebut, maka ibu bekerja dapat mencapai keberhasilan pemberian ASI eksklusif (Priyoto, 2014).

Distribusi pekerjaan ibu menunjukkan sebagian besar ibu bekerja sebagai buruh dan karyawan swasta. Sebagai buruh, maka waktu luang yang diberikan kepada bayi sangat singkat karena sebagian besar waktunya digunakan untuk bekerja. Minimnya waktu istirahat dan tidak adanya fasilitas penyimpanan ASI misalnya lemari pendingin, merupakan faktor-faktor yang menyebabkan dukungan tempat kerja terhadap pemberian ASI menjadi rendah. Implementasi kebijakan pemberian ASI eksklusif bagi ibu bekerja adalah pelaksanaan kebijakan bagi pekerja perempuan meliputi pemberian kesempatan atau waktu kepada pekerja perempuan untuk menyusui/ memerah ASI selama waktu kerja, sosialisasi, penyuluhan, pelatihan dan serta adanya kebijakan tertulis instansi yang mendukung pemberian ASI eksklusif dan juga fasilitas khusus untuk pelaksanaan pemberian ASI eksklusif di tempat kerja (Rahadian, 2014).

Menurut WHO (2011) setiap tempat sarana umum berupa fasilitas pelayanan kesehatan harus mendukung keberhasilan program pemberian ASI eksklusif dengan berpedoman pada 10 langkah menuju keberhasilan menyusui seperti mempunyai kebijakan tertulis tentang menyusui yang secara rutin disampaikan kepada semua staf pelayanan kesehatan. Namun pedoman khusus dari peraturan pemerintah untuk perusahaan di dalam menuju keberhasilan menyusui belum ada. Berkaitan dengan 10 langkah menuju keberhasilan bagi pelayanan kesehatan dapat diadopsi untuk perusahaan.

Berdasarkan hasil penelitian menunjukkan bahwa antara paritas dengan praktik pemberian ASI eksklusif didapatkan nilai $p$ value $=0,010$ maka dapat disimpulkan ada hubungan antara peemberian ASI Eksklusif dengan status paritas. Ibu yang memiliki anak lebih dari satu cenderung untuk mempraktikkan pemberian ASI eksklusif dibandingkan dengan ibu yang memiliki 1 anak. Hasil penelitian ini sejalan dengan penelitian yang dilakukan oleh Warille (2015) yang menyatakan bahwa ada hubungan antara paritas dengan pemberian ASI eksklusif.

Hasil penelitian ini juga didukung oleh penelitian yang dilakukan Yulianti (2014) yang menyatakan bahwa paritas berhubungan dengan pemberian ASI eksklusif. Berdasarkan nilai Odd Ratio menunjukkan bahwa responden yang status paritasnya primipara mempunyai peluang 6,889 kali untuk tidak memberikan ASI Eksklusif 
dibanding responden yang status paritasnya multipara. Hal ini sesuai dengan penelitian sebelumnya yang dilakukan oleh Mabud, Mandang \& Mamuaya (2014) menyimpulkan bahwa ada hubungan antara paritas dengan pemberian ASI eksklusif. Semakin tinggi tingkat paritas ibu maka berpengaruh positif terhadap pemberian ASI eksklusif. Jumlah anak mempengaruhi tingkat pengetahuan dan adanya pengalaman menyusui sebelumnya sehingga ibu yang mempunyai anak banyak akan memberikan ASI eksklusif. Pengalaman sebagai sumber pengetahuan adalah suatu cara untuk memperoleh kebenaran pengetahuan dengan cara mengulang kembali pengetahuan yang diperoleh dalam memecahkan masalah yang dihadapi di masa lalu. Kondisi ini menyebabkan, ibu yang multipara memiliki kemungkinan yang lebih besar untuk pemberian ASI eksklusif dibandingkan dengan ibu yang primipara.

Pengalaman menyusui pada kelahiran sebelumnya mempengaruhi seseorang untuk terus menyusui pada kelahiran-kelahiran setelahnya. Seorang ibu yang mengalami laktasi kedua dan seterusnya cenderung untuk lebih baik daripada yang pertama. Laktasi kedua yang dialami ibu berarti ibu telah memiliki pengalaman dalam menyusui anaknya. Begitu pula dalam laktasi ketiga dan seterusnya. Sedangkan pada laktasi pertama ibu belum mempunyai pengalaman dalam menyusui sehingga ibu tidak mengetahui bagaimana cara yang baik dan benar untuk menyusui bayinya (Musiskah, 2014). Teori ini didukung pula dengan hasil penelitian yang dilakukan oleh Destriatania, Februhartanty, dan Fatmah, (2013) yang menyatakan bahwa ibu yang mempunyai anak lebih dari 1 memiliki kecenderungan lebih besar untuk mempraktikkan ASI eksklusif dibandingkan dengan ibu yang baru memilikil anak.

Hasil penelitian menunjukkan bahwa pemberian ASI tidak eksklusif lebih banyak pada Ibu dengan pendidikan rendah, dibandingkan dengan Ibu yang mempunyai pendidikan tinggi dengan $P$ value $=0,037$ maka dapat disimpulkan ada hubungan antara pemberian ASI Eksklusif dengan status pendidikan. Tingkat pendidikan Ibu yang rendah mengakibatkan kurangnya pengetahuan Ibu dalam menghadapi masalah, terutama dalam pemberian ASI eksklusif. Pengetahuan ini diperoleh baik secara formal maupun informal. Ibu yang mempunyai tingkat pendidikan yang lebih tinggi, umumnya terbuka menerima perubahan atau hal-hal guna pemeliharaan kesehatanya. Pendidikan juga akan membuat seseorang terdorong untuk ingin tahu mencari pengalaman sehingga informasi yang diterima akan menjadi pengetahuan (Lestari, 2018).

Tabel 3. Hubungan antara (paritas, pendidikan, pengetahuan, dukungan keluarga, dan dukungan atasan) dengan Pemberian ASI Eksklusif ( $\mathrm{n}=51$ )

\begin{tabular}{|c|c|c|c|c|c|c|c|c|}
\hline \multirow{3}{*}{ Variabel } & \multicolumn{4}{|c|}{ Pemberian ASI Eksklusif } & & & \multirow{3}{*}{$\begin{array}{c}\text { OR } \\
(95 \% \mathrm{CI})\end{array}$} & \multirow{3}{*}{ Pvalue } \\
\hline & \multicolumn{2}{|c|}{$\begin{array}{c}\text { Tidak ASI } \\
\text { Eksklusif }\end{array}$} & \multicolumn{2}{|c|}{$\begin{array}{c}\text { ASI } \\
\text { Eksklusif }\end{array}$} & \multicolumn{2}{|c|}{ Total } & & \\
\hline & $\mathbf{f}$ & $\%$ & $\mathbf{f}$ & $\%$ & $\mathbf{f}$ & $\%$ & & \\
\hline \multicolumn{9}{|l|}{ Paritas } \\
\hline Primipara & 31 & 83,8 & 6 & 16,2 & 37 & 100 & \multirow{2}{*}{6,889} & \multirow{2}{*}{0,011} \\
\hline Multipara & 6 & 42,9 & 8 & 57,1 & 14 & 100 & & \\
\hline \multicolumn{9}{|l|}{ Pendidikan } \\
\hline Rendah & 19 & 90,5 & 2 & 9,5 & 21 & 100 & 6,333 & 0,037 \\
\hline Tinggi & 18 & 60 & 12 & 40 & 30 & 100 & & \\
\hline \multicolumn{9}{|l|}{ Pengetahuan } \\
\hline Kurang & 22 & 88 & 3 & 12 & 25 & 100 & 5,378 & 0,035 \\
\hline Baik & 15 & 57,7 & 11 & 42,3 & 26 & 100 & & \\
\hline \multicolumn{9}{|l|}{ Dukungan keluarga } \\
\hline Kurang Mendukung & 24 & 88,9 & 3 & 11,1 & 27 & 100 & 6,769 & 0,014 \\
\hline Mendukung & 13 & 54,2 & 11 & 45,8 & 24 & 100 & & \\
\hline \multicolumn{9}{|l|}{ Dukungan atasan } \\
\hline Kurang Mendukung & 23 & 92 & 2 & 8 & 25 & 100 & 9,857 & 0,006 \\
\hline Mendukung & 14 & 53,8 & 12 & 46,2 & 26 & 100 & & \\
\hline
\end{tabular}


Faletehan Health Journal, 7 (1) (2020) 18-29

www. journal.Ippm-stikesfa.ac.id/ojs/index.php/FHJ

ISSN 2088-673X | 2597-8667

Penelitian yang dilakukan oleh Sandiwana pada tahun 2011 di Wilayah Kerja Puskesmas Lubuk Kilangan Padang menyebutkan bahwa persentase pemberian ASI tidak Eksklusif lebih besar pada Ibu dengan tingkat pendidikan yang rendah $(85,7 \%)$ dibandingkan dengan Ibu yang memiliki tingkat pendidikan tinggi $(57,4 \%)$. Secara statistik terdapat hubungan yang bermakna antara tingkat pendidikan responden dengan pemberian ASI Eksklusif dengan $p$ value $=0,019$. Penelitian yang dilakukan Lestari tahun 2018 di Puskesmas Tapung Perawatan menyebutkan bahwa terdapat hubungan bermakna antara tingkat pengetahuan Ibu terhadap perilaku pemberian ASI Eksklusif $(\mathrm{p}=0,008)$.

Hasil penelitian menunjukkan bahwa pemberian ASI tidak eksklusif lebih banyak pada Ibu yang dengan pengetahuan kurang (88\%), dibandingkan dengan Ibu yang mempunyai pengetahuan baik $(57,7 \%)$ dengan $P$-value $=0,035$ maka dapat disimpulkan ada hubungan antara pemberian ASI Eksklusif dengan pengetahuan. hal ini dikarenakan masa kehamilan merupakan masa dimana Ibu siap memutuskan memberikan ASI eksklusif kepada anak atau tidak. Banyak sekali faktor yang mempengaruhi Ibu dalam memutuskan dan melakukan pola pemberian ASI, terutama kekurangsiapan fisik maupun psikis Ibu, kurangnya informasi dan pengetahuan mengenai manfaat ASI, manajemen laktasi dan hal-hal berkaitan dengan pemberian ASI.

Hasil penelitian ini sesuai dengan penelitian yang telah dilakukan oleh Tarigan, Aryastami (2012) yang menyatakan bahwa faktor pengetahuan merupakan pemicu seseorang untuk memberikan ASI eksklusif. Penelitian yang dilakukan Aprilia (2012) juga menyatakan bahwa ada hubungan antara tingkat pengetahuan ibu tentang ASI eksklusif dengan praktik pemberian ASI eksklusif. Dengan demikian perlunya pendidikan kesehatan tentang bagaimana cara memerah ASI selama bekerja akan mempengaruhi keberhasilan ibu bekerja dalam memberikan ASI secara Eksklusif, Hasil analisis menunjukkan terdapat hubungan yang signifikan antara pengetahuan ibu menyusui yang bekerja tentang pemberian ASI perah dengan pendidikan ibu $(\mathrm{p}=0,036)$. Dengan adanya pengetahuan ibu tentang pemberian ASI perah akan meningkatkan pemahaman yang mendalam pada ibu tentang manfaat pemberian ASI. Pemahaman ini akan menjadi dasar bagi ibu untuk berperilaku memberikan ASI perah kepada bayinya (Nurhayati $\&$ Nurlatifah, 2018).

Hasil penelitian didapatkan bahwa pemberian ASI tidak eksklusif lebih sedikit pada Ibu yang kurang mendapat dukungan keluarga $(88,9 \%)$, dibandingkan dengan Ibu yang mendapat dukungan dari keluarga $(54,2 \%)$ dengan nilai $P$ value $=0,014$ maka dapat disimpulkan ada hubungan antara pemberian ASI Eksklusif dengan dukungan keluarga. Dukungan keluarga sangat signifikan mungkin dapat dikarenakan tingginya kemauan ibu untuk memberikan ASI kepada bayinya sehingga ibu yang didukung secara cukup maupun baik oleh keluarga sama-sama mempunyai kesempatan untuk memberikan ASI secara eksklusif. Hal ini menunjukkan bahwa usaha dalam memberi dukungan dalam pemberian ASI eksklusif tidak akan sia-sia apabila ibu memiliki kemauan yang keras.

Dari hasil analisis diperoleh pula nilai $\mathrm{OR}=$ 6,769 , artinya responden yang kurang mendapatkan dukungan dari keluarga mempunyai peluang 6,769 kali untuk tidak memberikan ASI Eksklusif dibanding responden yang mendapatkan dukungan dari keluarga. Dukungan keluarga sangat berpengaruh terhadap proses memberikan ASI eksklusif khususnya pada ibu bekerja. Hal ini dikarenakan keluarga adalah lingkungan yang paling dekat dengan ibu. Keluarga juga perlu mengetahui informasi tentang ASI eksklusif dan cara memberikan ASI eksklusif pada ibu bekerja. Sehingga keluarga dapat meyakinkan ibu dan membuat ibu tidak merasa sendiri dalam merawat bayi. Dukungan keluarga juga sangat berpengaruh pada pengambilan keputusan untuk memberikan ASI eksklusif pada ibu bekerja (Prasetyono, 2012). Teori ini dikuatkan dengan hasil penelitian yang dilakukan oleh Zakiyah (2012) yang menyatakan bahwa dukungan suami, ibu, dan mertua berhubungan dengan praktik pemberian ASI.

Dukungan keluarga dari sekitar ibu mempunyai peran yang besar terhadap keberhasilan menyusui. Dukungan itu berasal dari lingkungan disekitar ibu selain suami, juga ada keluarga misalnya nenek dan keluarga lain yang sudah mempunyai pengalaman menyusui, peran nenek biasanya yang lebih dominan terhadap ibu. Dukungan suami/keluarga yang bagus akan senantiasa mendukung ibu dalam menumbuhkan 
sikap yang positif dalam pemberian ASI (IDAI, 2010).

Hal ini mendukung penelitian yang dilakukan oleh Mazza, Nunes, Tararthuch, \& Alexandre (2014), bahwa ada dua kategori yang berpengaruh dalam pemberian ASI, salah satunya adalah pengaruh sosial primer. Jaringan Primer ditandai oleh anggota keluarga dan orang-orang dekat. Suami dapat berperan dalam meningkatkan percaya diri ibu dalam memberikan ASI, kepercayaan diri ibu dapat meningkatkan produksi ASI. Rodrigues, Padoin, De Paula \& Guido (2013) menyatakan bila ibu yang mendapatkan dukungan dari anggota keluarga, terutama suami atau pasangan dan kakek nenek, berpengaruh positif terhadap kepercayaan diri terhadap menyusui. Anggota keluarga harus mendukung ibu dan membantu ibu dalam hal pemberian ASI sehingga ibu merasa mampu untuk menyusui.

Hasil penelitian didapatkan bahwa pemberian ASI tidak eksklusif kurang memiliki dukungan dari atasan yaitu sebanyak 23 responden (92\%), dibandingkan dengan Ibu yang mendapat dukungan atasan $(53,8 \%)$ dengan nilai $P$ value $=0,006$ maka dapat disimpulkan ada hubungan antara pemberian ASI Eksklusif dengan dukungan atasan. Ibu yang mendapatkan dukungan, cenderung lebih banyak yang memberikan ASI eksklusif dari pada yang kurang mendapat dukungan dari atasan langsung. Sebagian besar responden mengakui bahwa atasan di tempat kerja kurang mendukung tentang ASI eksklusif. Atasan juga tidak memberikan waktu khusus untuk memerah ASI. Hanya sebagian kecil $(26,9 \%)$ atasan yang mendukung pemberian ASI ekkslusif.

Hasil penelitian ini sejalan dengan penelitian yang dilakukan oleh Permatasari (2015) bahwa terdapat perbedaan antara ibu yang mendapat dukungan dari atasan dan ibu yang tidak mendapat dukungan dari atasan. Ibu yang mendapat dukungan dari atasan sebanyak $10 \%$ memberikan ASI eksklusif. Sedangkan yang tidak mendapat dukungan dari atasan hanya sebanyak 3,3\% yang memberikan ASI eksklusif. Begitu pula penelitian yang dilakukan oleh Rizkianti, Saptarini, Novianti, dan Prasodjo, (2014) yang menyatakan bahwa dukungan atasan kerja merupakan faktor yang berperan dalam keberhasilan pemberian ASI eksklusif pada ibu bekerja. Namun berbeda dengan hasil penelitian yang dilakukan oleh Abdullah dan Ayubi (2013) yang menyatakan bahwa dukungan atasan langsung tidak berhubungan dengan pemberian ASI eksklusif pada ibu pekerja.

Hasil analisis data menunjukkan nilai $\mathrm{OR}=9,857$, artinya responden yang kurang mendapatkan dukungan dari atasan mempunyai peluang 9,857 kali untuk tidak memberikan ASI Eksklusif dibanding responden yang mendapatkan dukungan dari atasan. Dalam mencapai keberhasilan memberikan ASI eksklusif khususnya bagi ibu yang bekerja, dukungan atasan tentu sangat dibutuhkan. Toleransi dan kebijakan khusus yang diberikan bagi ibu menyusui untuk memerah ASI pada jam kerja tentu akan berdampak positif pada pemberian ASI eksklusif oleh ibu bekerja. Selain itu apabila dilengkapi dengan fasilitas memadai di tempat kerja tentu akan menambah peluang lebih untuk memudahkan ibu bekerja untuk memberikan ASI eksklusif (Damayanti, 2013).

Berdasarkan penelitian yang dilakukan oleh Pratiwi (2016) salah satu faktor yang berhubungan dengan pemanfaatan ruang laktasi ialah dukungan atasan. Sehingga atasan berperan penting dalam program ASI eksklusif oleh karyawannya. Penelitian yang dilakukan oleh Setyawati \& Sutrisminah (2012) menyatakan bahwa faktor lingkungan yang sangat mempengaruhi perilaku menyusui pada ibu bekerja berasal dari pimpinan perusahaan yang mempunyai kekuasaan untuk membuat kebijakan dan menyediakan fasilitas menyusui selama bekerja. Oleh sebab itu, dukungan atasan langsung sangat penting bagi ibu bekerja agar ibu dapat memberikan ASI eksklusif kepada bayinya.

Dalam kajian teori Health Belief Model, dukungan atasan langsung merupakan isyarat untuk melakukan tindakan (Priyoto, 2014). Dukungan yang diberikan dapat berupa dukungan informasional, appraisal, instrumenal dan emosional. Misalnya dengan memberikan informasi tentang manajemen laktasi dan ASI eksklusif serta memberikan waktu khusus untuk memerah ASI. Dengan dukungan tersebut, maka ibu bekerja dapat mencapai keberhasilan pemberian ASI eksklusif.

\section{Simpulan}

Faktor yang paling berhubungan permberian ASI eksklusif pada ibu bekerja adalah dukungan keluarga dan dukungan atasan, dimana mereka memiliki peranan penting dalam memfasilitasi kebutusan sarana dan prasarana untuk memerah 
Faletehan Health Journal, 7 (1) (2020) 18-29 www. journal.Ippm-stikesfa.ac.id/ojs/index.php/FHJ ISSN 2088-673X | 2597-8667

ASI dan juga di berikan waktu untuk menyusui bayinya. Oleh karena itu ibu yang bekerja harus mengoptimalkan pemanfaatan ruang laktasi dan tetap memberikan ASI eksklsuif kepada bayi.

\section{Referensi}

Abdullah, G.I dan Ayubi D, (2013), Determinan Perilaku Pemberian Air Susu Ibu Eksklusif pada Ibu Pekerja, Jurnal Kesehatan Masyarakat Nasional, Vol 7 No 7. pISSN:1907-7505 e-ISSN: 2460-060 DOI: http://dx.doi.org/10.21109

Adhi, M. (2013). Homemade healthy baby food, Masak sehat penuh cinta. Jakarta: Pandamedia.

Aprilia, G, (2012). Hubungan Tingkat Pengetahuan Ibu Tentang ASI eksklusif dengan pemberian ASI eksklusif di Desa Harjobinangun Purworejo, Jurnal Komunikasi Kesehatan (Edisi 5), 3(2).

Arikunto, S. (2013). Prosedur Penelitian: Suatu Pendekatan Praktik. Jakarta: Rineka Cipta

Astutik RY. (2014). Payudara dan laktasi. Jakarta: Salemba Medika.

Ayton, J \& Emily H. (2016). Complex young live : a collective qualitative case study analysis of young fatherhood and breastfeeding, International Breastfeeding Journal, $11: 6$. DOI 10.1186/s13006-016-0066-9.

Badan Pusat Statistik (2014) Statistik Indonesia: Statistical Yearbook of Indonesia. 2013. Badan pusat statistic.http://www.bps.go.id

Ballard O, Morrow AL. (2013). Human milk composition: Nutrients and bioactive factors. Pediatr Clin North Am. 60(1):49-74. doi: 10.1016/j.pcl.2012.10.002.

Baron, Robert A \& Byrne, Donn. (2002). Psikologi Sosial Jilid 2 (Edisi Kesepuluh). Jakarta: Erlangga

Buonocore G, Bracci R, Weindling $\mathrm{M}$. (2013).Neonatology: A practical approach to neonatal diseases. Alih Bahasa Buonocore. Milan: Springer.

Dahlan, A., Mubin, F., \& Mustika, D.N., (2013). Hubungan Status Pekerjaan Dengan Pemberian Asi Eksklusif di Kelurahan Palebon Kecamatan Pedurungan Kota Semarang. Jurnal Kebidanan 2 (2). DOI: https://doi.org/10.26714/jk.2.2.2013.56 $-60$

Damayanti, D. (2013). Asyiknya Minum ASI. Jakarta: PT. Gramedia Pustaka Utama
Depkes. (2001). Strategi nasional peningkatan pemberian ASI (PP-ASI). Jakarta : Departemen Kesehatan Republik Indonesia.

Destriatania, S; Februhartanty,J; Fatmah (2013), Sikap Ayah dan Jumlah Anak serta Praktik Air Susu Ibu Eksklusif, Jurnal Kesehatan Masyarakat Nasional, Vol. 8, No. 5, 229-234. DOI: http://dx.doi.org/10.21109/kesmas.v8i5 .389

Febriyanti, R., \& Ernawati, D. (2015). Analisis Faktor-Faktor yang Mempengaruhi Pemberian ASI Eksklusif di Desa Gilang Taman Sidoarjo. Jurnal Keperawatan. Diakses pada tanggal 28 Oktober 2018, Dari https://www.e-jurnal.com/2015/12/analisisfaktor-faktor-yang.html.

IDAI. (2010). Bedah ASI, Jakarta: Balai Penerbit FKUI

. (2010).Indonesia Menyusui. Jakarta : Badan Penerbit IDAI

Jalal, F. (2014). Fasli. 20 Peneliti untuk Pengabdian yang Konkret dalam Pembangunan Negara dan Bangsa_149910 Naskah Orasi Ilmiah. Jakarta: LIPI dan BKKBN

Josefa, K.G , Margawati A. (2011). Faktor-faktor yang Mempengaruhi Perilaku Pemberian ASI Eksklusif pada Ibu (Studi Kasus di Wilayah Kerja Puskesmas Manyaran, Kecamatan Semarang Barat. Artikel Penelitian. Semarang: Program Pendidikan Sarjana Kedokteran. Fakultas Kedokteran. Universitas Diponegoro.

Kemenkes RI. (2013). Peningkatan Pemberian Air Susu Selama Waktu Kerja di Tempat Kerja. Jakarta: Direktorat Bina Kesehatan Kerja

Kurniawati, D. (2014). Faktor Determinan yang Mempengaruhi Kegagalan Pemberian ASI Eksklusif pada Bayi Usia 6-12 bulan di Kelurahan Mulyorejo Wilayah Kerja Puskesmas Mulyorejo Surabaya. Skripsi. Program Studi Kesehatan Masyarakat: Universitas Airlangga.

Lestari, R.R.(2018). Faktor-faktor yang berhubungan dengan pemberian ASI Eksklusif pada ibu. Jurnal obsesi: Jurnal Pendidikan anak usia dini. 2(1) 131-136. pISSN 2356-1327. e-ISSN 2549-8959. http://obsesi.or.id/index.php/obsesi

Mabud, N.H., Mandang, J., \& Mamuaya, T. (2014). Hubungan pengetahuan, pendidikan, paritas, dengan pemberian ASI eksklusif di 
Puskesmas Bahu Kecamatan Malalayang Kota Manado. Jurnal Ilmiah Bidan. 2(2), 5156. ISSN:2339-1731

Mazza, V.D.A., Nunes R.C.T., Tararthuch, R.Z.P \& Alexandre, AMC. (2014). Influence of social support networks for adolescent breastfeeding mother in the process of breastfeeding. International Breastfeeding Journal, 19, 1-7

Megasari, M. (2014). "Panduan Belajar Asuhan Kebidanan I'. Yogyakarta: Deepublish

Musiskah. (2014). Pengalaman ibu primipara dalam memberikan asi eksklusif di wilayah kerja Puskesmas Kleurahan Kembangan Utara Jakarta Barat. Skripsi. Universitas Islam Negri Syarif Hidayatullah. Jakarta.

Nasution, S.I., Liputo, N.I., \& Masri, M. (2014). Faktor-Faktor Yang Berhubungan Dengan Pola Pemberian ASI Eksklusif Di Wilayah Kerja Puskesmas Bungus Tahun 2014. Jurnal Kesehatan Anddalas. 5(3) 635-639. DOI: https://doi.org/10.25077/jka.v5i3.590

Notoatmodjo, S. (2014). Pendidikan dan Perilaku Kesehatan. Rineka Cipta. Jakarta.

(2014). Metodologi Penelitian Kesehatan. Jakarta : Rineka Cipta

. (2006). Metode Penelitian Kualitatif. Jakarta: Bumi Aksara

Nurfajria,A.E. (2017). Faktor-Faktor Yang Berhubungan Dengan Pemberian Asi Eksklusif Pada Ibu Bekerja Di Tempat Penitipan Anak Wilayah Kota Yogyakarta.. Jurnal Keperawatan 2 (1). di akses pada tanggal 20 Oktober 2018 dari http://etd.repository.ugm.ac.id/index.php?mo $d=$ penelitian_detail\&sub=PenelitianDetail\& $a c t=v i e w \&$ typ $=h t m l \& b u k u \_i d=109107 \&$ oby $e k \_i d=4$

Nurhatyati, F; Nurlatifah, S. (2018). Hubungan pengetahuan ibu menyusui tentang pemberian ASI perah dengan pendidikan ibu di Wilayah Kerja Puskesmas Cimahi Tengah. Jurnal Bidan "Midwife Journal" .4(02). 11-15, pISSN 2477-3441 eISSN 2477-345X

Nurheti, Y. (2010). Keajaiban ASI - Makanan Terbaik untuk Kesehatan, Kecerdasan, dan Kelincahan Si Kecil. Yogyakarta: CV. ANDI.

Permatasari, P, (2015). Gambaran Data Demografi Pemberian ASI Pada Wanita Pekerja Swasta di Desa Jetis, Wilayah Kerja Puskesmas Baki 1 Kabupaten Sukoharjo, Skripsi, Surakarta : Universitas Muhammadiyah Surakarta.
Prasetyono, D.S. (2012). ASI Eksklusif Pengenalan, Praktik dan Kemanfaatannya. Diva Press. Yogyakarta

Pratiwi, D, M. (2016). Analisis Faktor Penghambat Pemanfaatan Ruang Menyusui di Tempat Kerja Pada Pekerja Wanita di PT. Daya Manunggal, Unnes Journal of Public Health, $5(2)$.

DOI: https://doi.org/10.15294/ujph.v5i2.101 11

Priyoto, (2014). Teori sikap dan Perilaku dalam Kesehatan Dilengkapi Contoh Kuesioner, Yogyakarta : Nuha Medika.

Proverawati, E. (2010). Kapita Selekta ASI \& menyusui. Yogyakarta: Nuha Medika.

Rahadian, R.A. (2014). Pemenuhan Hak Asi Eksklusif Di Kalangan Ibu Bekerja: Peluang Dan Tantangan. Jurnal Kependudukan Indonesia 9 (2) 109-118. diakses pada tanggal $25 \quad$ Oktober 2018. http://ejurnal.kependudukan.lipi.go.id/index. php/jki/article/download/40/26.

Rizkianti A; Saptarini, I ; Novianti, Prasodjo, R. (2014). Analisis Faktor Keberhasilan Praktik Pemberian Asi Eksklusif Di Tempat Kerja Pada Buruh Industri Tekstil Di Jakarta, Buletin Penelitian Kesehatan, 42 (4), Hlm : 237-248.

Rodrigues A P; Padoin S M, D; De Paula C C, \& Guido D A. (2013). Factors those influence in self efficacy of breastfeeding. Journal of Nursing7(5), 4144-4152. DOI: 10.5205/reuol.4134-32743-1-SM1.0705 esp201307.

Roesli, U. (2008). Manfaat ASI dan Menyusui. Jakarta: FKU

Sandiwana B. (2011). Faktor-faktor Yang berhubungan dengan pemberian ASI eksklusif di wilayah kerja Lubuk Kilangan Padang (skripsi). Padang: PSIKM Universitas Andalas

Sarwono, Sarlito Wirawan. (2004). Teori-teori Psikologi Sosial. Jakarta:PT Raja Grafindo Persad

Setyawati, I \& Sutrisminah, E. (2012). Pentingnya Motivasi dan Persepsi Pimpinan Terhadap Perilaku Pemberian ASI Eksklusif Pada Ibu Bekerja. Majalah Ilmiah Sultan Angung. 50 (127).

Soetjiningsih. (2012). ASI Petunjuk untuk Tenaga Kesehatan. Jakarta : Penerbit Buku Kedokteran EGC. 
Faletehan Health Journal, 7 (1) (2020) 18-29

www. journal.Ippm-stikesfa.ac.id/ojs/index.php/FHJ

ISSN 2088-673X | 2597-8667

Tarigan, I. U; Aryastami, N.K. (2012). Pengetahuan, Sikap Dan Perilaku Ibu Bayi Terhadap Pemberian Asi Eksklusif. Jurnal Penelitian Sistem Kesehatan. Buletin Penelitian Sistem Kesehatan , 15 (4), 390397

Timporok, A.G.A; Wowor, P.M; Rompas, S. (2018). Hubungan Status Pekerjaan Ibu Dengan Pemberian Asi Eksklusif Di Wilayah Kerja Puskesmas Kawangkoa. Jurnal Keperawatan. 6(1) ,1-6 diakses pada 20 Oktober

2018https://ejournal.unsrat.ac.id/index.php/j kp/article/download/19474/19025

Undang - Undang RI No 36 Tahun 2009 tentang Kesehatan. (2009). Jakarta

Walyani, E. S. (2015). Perawatan Kehamilan dan Menyusui Anak Pertama agar Bayi Lahir dan Tumbuh Sehat. Yogyakarta : Pustaka Baru Press.

Warille, E, B. (2015), Knowledge And Practice Of Exclusive Breastfeeding Among Women With Children Between 9 And 12 Months Of
Age In El Sabbah Hospital Juba-South Sudan, Tesis, Nairobi, University of Nairobi.

WHO. (2011). Pengertian ASI Eksklusif. Jakarta: World Health Organization

Yulianti, F, (2014). Hubungan Antara Karakteristik, Tingkat Pengetahuan Dan Dukungan Keluarga Terhadap Pemberian Asi Eksklusif Di Wilayah Kerja Puskesmas Siantan Hulu Kecamatan Pontianak Utara Tahun 2014, Jurnal Mahasiswa Fakultas Kedokteran Universitas Tanjungpura, Vol 1 No 1.

Yusrina, A; Devy, S.R. (2016). Faktor Yang Mempengaruhi Niat Ibu Memberikan Asi Eksklusif Di Kelurahan Magersari, Sidoarjo. Jurnal Promosi Kesehatan. 4(1). 11-21 pISSN 2085-3475, e-ISSN 2540-9972

Zakiyah. (2012). Faktor-faktor yang berhubungan dengan pemberian ASI Eksklusif di Kelurahan Semanan Kecamatan Klaideres Jakarta Barat. Skripsi. Universitas Indonesia. 